\title{
A VIEW ON PATHOGENESIS OF TYMPANOSCLEROSIS.
}

\author{
By \\ Toshiro GOTO, M.D. \\ From the department of Otorhinolaryngology, Nagasaki \\ University School of Medicine.
}

Recently tympanosclerosis and its relation to mpanoplasty has been called to the attention of e otologists, but its pathogenesis is not throughly scussed and explained satisfactorily.

Tympanosclerosis may be a sequele of chronic flammation in the attic with limited pneumatizam. According to the pneumatization theory the ucosa of the middle ear with limited pneumatition may demonstrate fibrous thickning, which istructs the attic space, enclosing the ossicular. ibration of the ossicular chain may transform the rous tissue into hyaline or calcareous tissue, hich is called hyaline or calcareous plate. These lcareous plate makes an articulation with the ossicular chain and may correspond to the intraarticulation cartilage "Meniscus"

The author has assumed that the fibrous thickning of attic mucosa might be related, to the sensitive constitution of the skin and mucosa but not in the sense of allergy.

As to the invasive form of tympanosclerosis the author presumed that in this form the contact of the ossicles with the attic wall can occur as abnormal process of pneumatization before the attack of inflammation. As the author previously had reported in this journal, severe inflammation can can cause the sclerotic change of the mucosa of the air cells, leading to fibrous change of the bone wall.

\section{Tympanosklerose に 就いて}

\section{長崎医科大学耳鼻㸶㗱科学教室}

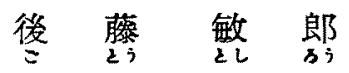

Tympanosklerose は聴力增進の手術が流行するよう なつてから，再び注意されるようになつた revival 疾 にの一つである。最近では1959年 Zöllner 及び Beck による“Paukensklerose”としての9例の発表に引 続いて 1961 年 Irwin Harris ${ }^{5)}$ の 16 例及び Goodhill 3)の Pseudootosklerose の一つの病変としての紹介 広く本症への注意老㬇起するに役立つた。

本邦に扣いてる1961 年川因 ${ }^{10)}$, 藤沢 ${ }^{8)}$ の雨氏は夫љ 症の 13 例及び 7 例を報告し，鼓室成形術を行ら場合 本症の存在することへの注意を噞起した。

しかし，以上の報告のあるにも拘らず，本症を一つの 立性の疾婁とすることに就いては病像の輸廝は明確を き，ての発症の機序については深く論ぜられたものを ない，最近著者は，3例の庭例を観察することができ ので，文献に記载されたところを参考にしつつ，著者
の含気空学説の立場からその Pathogenese に就て考え てみることとした。

この中耳の病変が最初に注意されて記載されたるのは 1869年 Tröltsch によることはいずれの文献も一致し ているところである，彼はこの病変を粘膜が硬化し，弾 性を失つてくるために，鼓膜の振動をさまたげ，Stapes 周囲の膜状部及び正円空膜の石死沈着あるいはその骨化 をさたすためにこの部位にも完全な Ankyloseををた

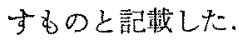

Tympanosklerose に効する古い時代の 文献は入手が 困難であるために，Harris ${ }^{5}$ の論尖の中から摘録する と次のようである。

Walb が Schwartze の教科書に記载してあるものも， 鼓室粘膜の sclerosis は hyaline Degeneration を伴つ た硬い繊維性の組織よりなり，その变化は糊莫の深尿よ 


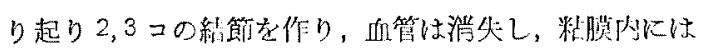
小数の石灰の沈着が認められるとしている。

その後 Winslow (1882), Pcmerey (1883) 更に John Roosa (1891) 等は慢性牛耳炎に和子る粘膜の維維性及 び骨化性の变化に就てふれているとされている。

Politzer ${ }^{1)}$ は1908 年版の Lehrbuch der Ohrenheilkunde の中に，慢性中耳㶤の結果として，鼓空の上部 は耳小骨は包九た愿い粘膜や Kalkmasseに埋するbれ

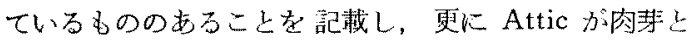

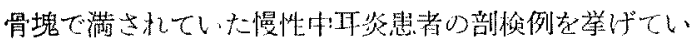

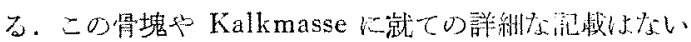

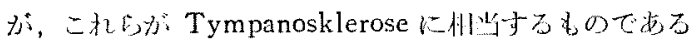
ことは確罢のようである。

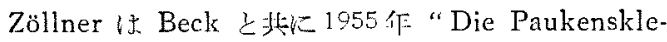
rose”の題目のもとに椾の9 例定献告しているが、こ の題日は Tröltsch の用いた名称が妥当であるから，そ のまま用らることとしたと䟧いてある。

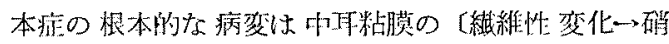
子化一雷形成 といつた一連の退行性桨化であつて，

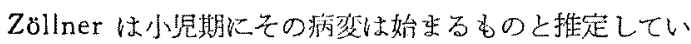
る. 㨱膜所見は多くは穿孔があつて慢性中耳资の現存し ている例が多いが，又，敖膜に不灰の沈着があつて慢性 中耳资の経過したことを示す例む多い，しかし，そうし た所見の認められない例るあるとした。鼓室粘膜に石灰 の沈着が Exostose 状に突出して見党，消息子で硬くふ れる例も認められ，㯖力の障害程度は病変のいかんによ つて異るとした，鼓宝が粘膜の肥厚によつて完全に充塞 されている例もあり，粘膜には一部に象牙様の色彩を呈 している部分があるとした。この白の部位の表現に “Zuckerguss”という害葉が用いら猄ている。 Zuckerguss とは肝又は脾が脂胙变性の際に呈する表面の白つ ぽい色調を指していら。これらの変化はAttic が主で あつて、, Mastoidzellen には少数例に認められるとし t心.

重要な所見は “Kalkschale” 又住 Hyalinschale と 呼ばれている変化である。これは耳小骨と午の接着する

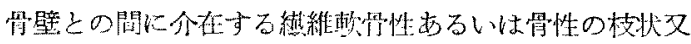
は，王憼の镂片状の絹織片を指すのであつて，多くは1 〜2mm の厚さで容易に分離でさる。この Schale 状の 緗䋘の存在が本症の病像の特異性を示与上にも，Patho-

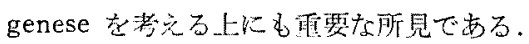

Goodhill 2) 仗1960年に pseudootosclerose に就ての 報告の中で!例の Tympanpsclerosis 孝跟出した。

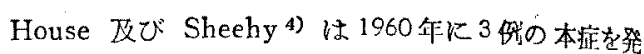
表し, cholesteatom 及び Otosclererosis との鑑別々 いて述べ，本宣は手術によつて sclerosis の部分を除去 することによつて，腽少の回復の得られることを埌し 必.

Harris $(1961)^{5)}$ の献告は Goodhill 女共同にて観察

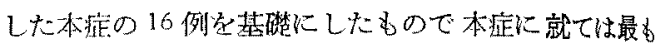

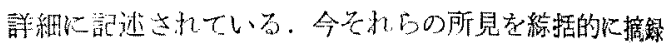
す木は次の如くで市る。

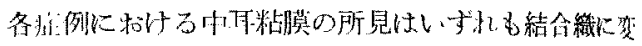

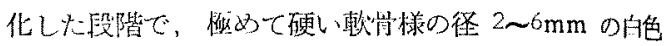

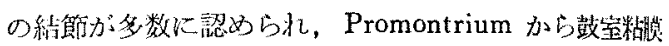

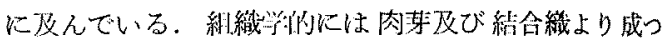

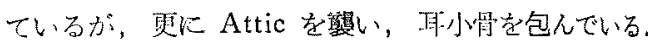
Tympanosclerose の留も印像的なるので蛙 Aditus 及 $ひ ゙$ Attic 全く充䈏し, Incus の体部に刘して bed

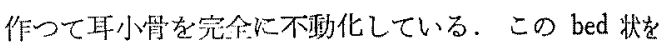

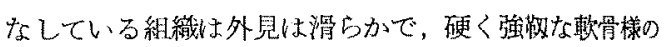
組織であるとした，これが，Zöllner の Hyalinschale 㕛林 Kalkschale と呼九でいるものに相当するものであ

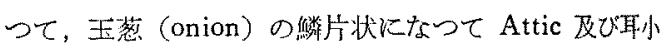

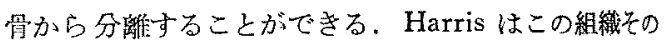
むのる tympanosclerosis と呼んでいる，この硬化組蟣 には2種あるとしている点も本症の病像を考克る上に重 要な点である.

第一の型のbのはその Schale 状の組織の下に正常な 粘膜上皮が認められるるのであつて，第二の型のものは

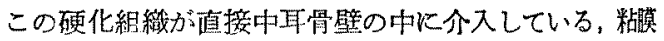
上皮又は骨膜を残さないものである。

前者を彼は表在型 superficial form 又 benign or sclerosing form, 他のものは破鉬型 invasive form 叉 it destructive or osteoclastic periostitis form $と$ 呼 九た。

- Harris $の$ consulting pathologist Dr. Leo Weiss の意見によると tympanosclerosis の組䋘所見は次のよ らに要的されている。

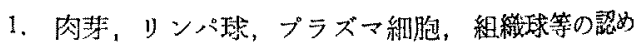

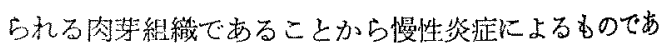
るこ上は碓かである。

2. 硝子化即ち sclerosis の楒めら机る硬い fibrosis の所晃.

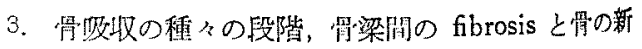
I. 
4. 病変を被う上皮細胞は円柱状のものから角化扁平 皮まで種々の型のるのが認められている。

5. ある3例では出血栄と出血による hemosiderin 含んだ肉芽が認められている。

6. Tympanosclerosis は急性の mastoiditis 又は olesteatom の存在の際にも認められている.

残念ながら上記病变の存在している部分の中耳腔にお る位置的関係が明らかでない，又，Kalkschale に就 は記載がない。

病因を考光る上に重要な所見として注意されるもの ，本症の発症年令であって，こ机については Harris 意見がある. Harris は300 例の mastoid-op.のちち 本症は $5.2 \%$ に認められるとしているが，小児は66 例 手術例中本症は認められていないことから，彼は，本 の現れるには恐らく 15〜20年の長期を要するである としている.この意見は，Zöllner が本症は恐らく小 期から病翏溌症しているものであるうとしている意 之相通ずるむのがある。この点については著者の庭例 2は重要な反対的意見の資料を提供している。

Zöllner が, 病変組織並に血中に Eosino 細胞の增多 の認められたことから，本症の誘因として Allergie 挙げたが, Harris の症例では Allergie 証明する所 は得られていないこの点については著者も Allergie 見組織学的には認めていない。

以上の多数の旧時代の報告は本症に就て詳細に描写し あるが，本症を一つの特異な中耳の疾患として緸める めには病像の輸猛が 明らかでない部分があるととる ，その Pathogenese に就ては殆んど追及されていな

著者は以上の文塥に記述されている所見を参考にしな 15，次挙げる3例を基礎にして著者の Pneumatisionslehre の立場から本症の病像と共にその Pathoglese について考察を試みたい

症例 1. T. 22 才八?

酳側慢性中耳炎, 右 Tympanosclerose. 1962 年両側 Mastoid op. $5 く$ 。单純手術の如し.

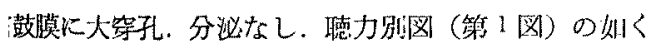
渡の伝音難㯖の所見. 1963 年. Tympanoplastik N

手術所見，Planum mastoideaに骨欠損あれども乳様 漟は小指頭大の洞状をなし，粘膜中等度に堙脹するの にて分泌なし, Aditus and Antrumは耳小骨とその 㓻の肉芽にて完全に充塞. Ambos の体部及び Ham.
第1图第1例の術前術後のオージオダラム

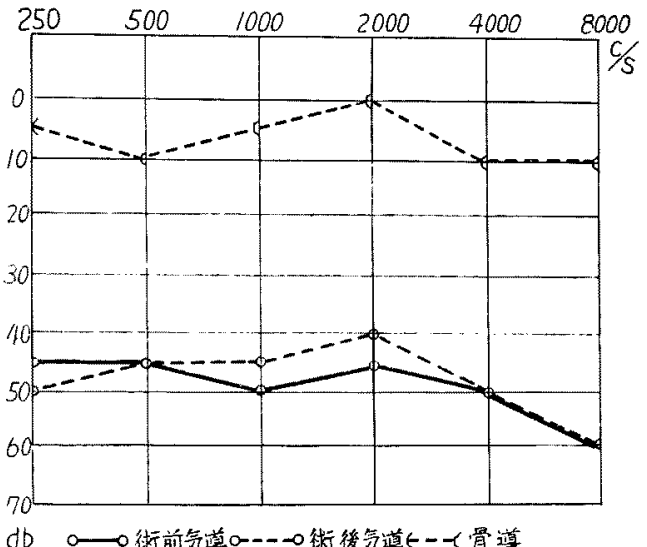

mer の頭部と内側骨壁との間に扁西な所謂 Kalkschale が介在して耳小骴は全く不動.

耳小骨を除去し Tympanoplastik の3型を行引。術 後の聴力は（第1图）の如く改善が得られていない。

組織学的所見：耳小骨周囲の肉芽は fibrös な絰密な 結合組織よりなり，血管は少なく，浸潤も少ない，小 Cyste 飞富も，耳小骨の周囲の Kalkschale の大部分は 緻密な骨組織より成つているが，一部に fibrös な骨組 織の部分が認めらる. Mastoidzellen の粘膜の上皮緗胞 は不明であるが，fibrös で一部に hyalin 様の変化を示 し，細胞の浸潤は少ない，多数の小 Cyste 腔あり，そ の内容は多種。

本症は組織学的にも臨休的にも Tympanosclerose と することができる所見である。

\section{症例 2.I.17才早}

両側慢性中耳炎, 左 Tympanosklerose.

両側豉膜中央に大穿孔あり。残存部に石灰沈着，1961 年 3 月. Tympanoplastik.

左側は当持鼓室粘嗼の尰脹軽度で，聴力別図の如く損 失軽度なれば mastoidを開かずに中耳粘膜も残して外 耳道皮弁による Tympanoplastik I 学行ら。Pneumatisation 抑制高度.

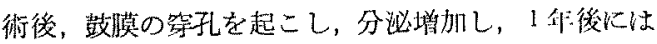
鼓室粘膜の腫脹高度, 後上部に粘漠白色化した部位が認

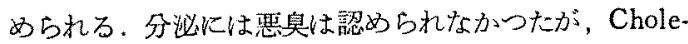
steatomを合併したものと診断して，1963年5月再手 術を行い，本症が Tympanosklerose であることを発見 した，再手術前の聴力性 2 园に示主如く低下し，第一 回手術前の聴力に比して雚しく悪化. 
第 2 図 第 1 例の左耳の術前術後のオージオグラム

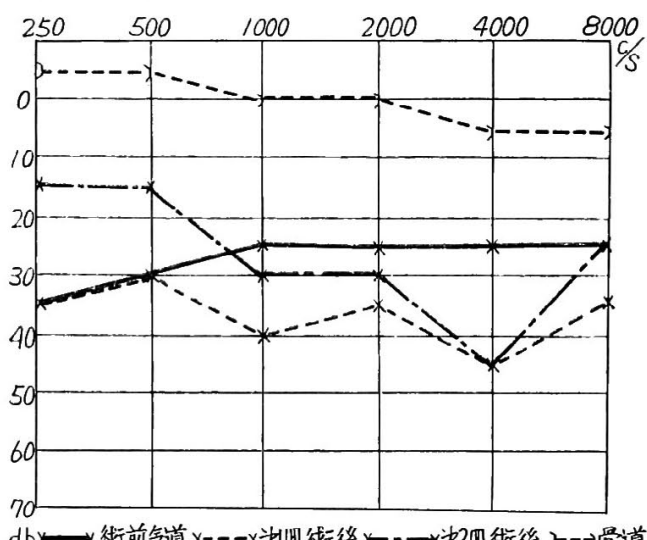

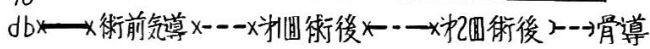

手術所見，耳小骨は因芽に被れ Attic 及び Aditus を完全に充塞寸. Mastoid 腔は中等度大の洞状，分泌 なきも粘膜は高度に腫脹. 但し, Facialiswulst の垂直 部に相当して，粘膜は狭い帯状で白色の腱状に変色した 部が認められた。この部分は薄くして, 硬く, 骨壁とは 比較的固く癒着していたが，剝離は可能で骨壁は正常で 滑かであつた。

耳小骨と内壁との間に骨様の 組織あり (写真 1,2 ) Ambos の接する迷路後部骨壁では一部遊離した小骨塊 の部分あり. 正常蜂巢壁の耳小骨に接した一部が分離し た状態の骨片である。Ambos の長脚は吸収せられ， Ovalfenster の部分も白色の hyalin 様の物質にて充さ れ，除去するに Stapes は既に消失. Tympanoplastik IV 型を行う．この例は Allergie 性皮膚炎の既往症あり.

但し血液中及び組織中にはェオジン細胞及びAllergie

写真 1 嘚骨, 砧骨と所謂 Kalkschale

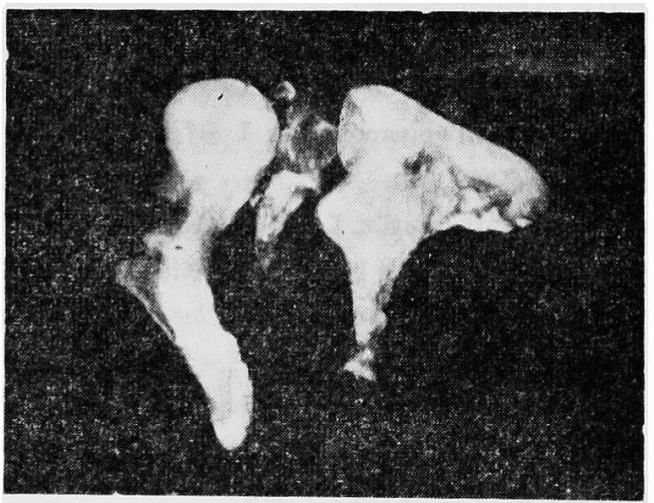

様変化は証明されていない。

組織学的所見：Kalkschale の部分は薄い板状の骨梁 よりなり，一面（耳小骨に接する）は粗糙な薄い絬合織

写真 2 所謂 Kalkschale

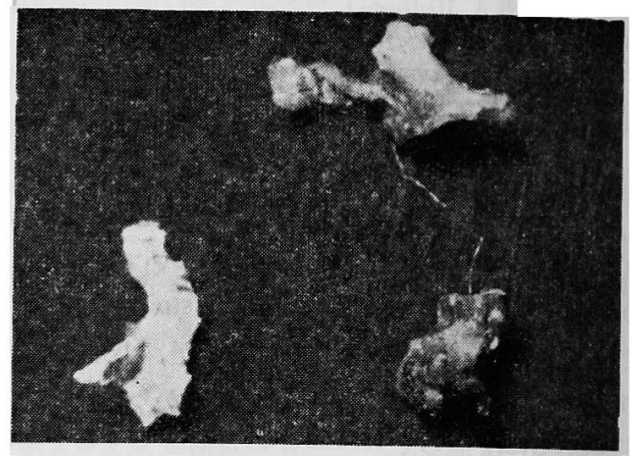

写真 3 所謂 Kalkschale（岩佐例）の組繳像

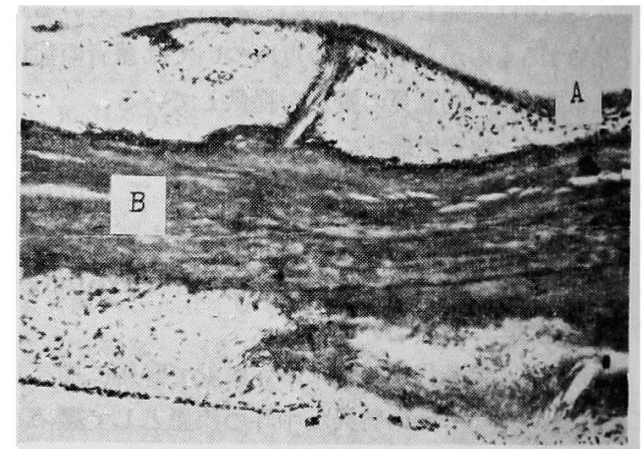

耳年骨に向つた面:(A)、注無構造の腱様の薄い層 が認められ，骨板（B）との間に Myxom 様の幼” 弱な結合織が認められる。他面は Cubischな上皮 細胞で被る。

写真 4 所謂IKalkschale（岩佐例）の組織像

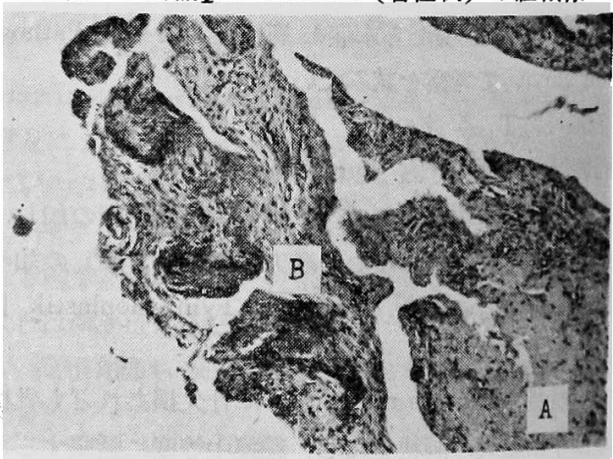

この Kalkschale は結合織の硝子様変性組織 (A) から成り，一部には骨新生（B）の所見が認められ る。 
物り，先の表層は homogen な骨膜様の Membran 波れている、他の面の骨壁に接した側では骨梁は 1yxomatös な組緎で被れているが，部分的には緻密な brös な組織に移行し，上皮の一部には cubisch な上 弾胞が㸾められる(写真 3). 他の Kalkschale では omogen な薄いKnochenplatte を被う硬い fibrösな 占合組織層が認められ，その内部には数コの幼弱な新生 片と，一部には hyalin 棣の変性部が認められる（写 (4).

白斑状の粘膜部位は，結合穖の薄く㬝状をなした組 ど硝子様变化の傾行を示し，浸濯は少なく，表層に omogen にエオシンに薄く染つた稍々厚い Membran 部分があつて，そのうらに少数の赤血球及び白血球 浛まれている，斯る部位が所謂 Zuckerguss と乎ぱれ 、部位に相当する。

本症は臨床的にも組織学的にも Tympanosklerose と 断することができる。しかる，第一回の手術後，約 1 :内外にて起つた病変であることはその聴力像から見て ，旺盛な骨增殖所見から見ても確かである。第二回手 後低音域衈力の回復は正门空の粘膜硬化による閌塞に :るためか。

症例 3. N. 40 才

左側慢性中耳炎, 左 Tympanosklerose,

5 才の頃に左耳より Otorrhoe があつたがその後停止 ていたすの，昨年 8 月より Otorrhoe の再発のため 治㙩をらけた。 現在 Otorrhoe は少量, 耳痛なし, 疅は各周波数 $60 \mathrm{db} \sim 70 \mathrm{db}$, Tympanoplastik 9 月， neumatisation は高度に抑制 Antrum 小, Aditus 及 ‘Attik は耳小骨及びこれを因緬する硬い肉芽塊にて

第3 图 第3 例の術前のオーヂオダラム

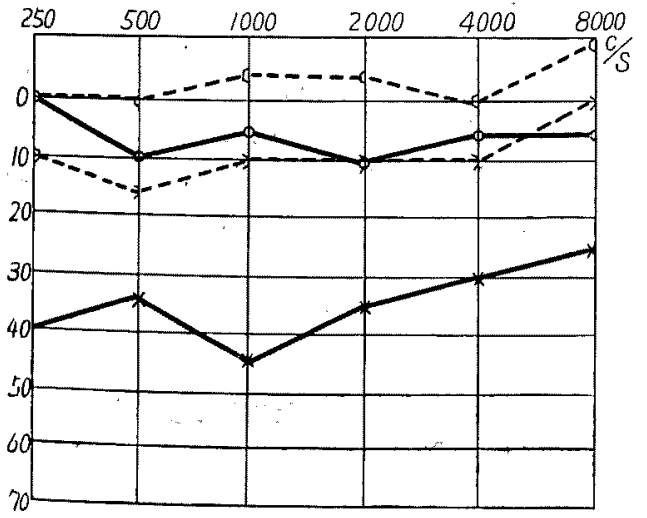

充塞せらる，肉莱塊は硬くうちに炶白色の小顆粒を混じ ている。耳小骨に対してこの組織㱱は bed 状をなし， 耳小骨より容易に分晟することがでさる、耳小骨関節は Ankylose を起し，Ambos の長脚も結合 織塊内に埋 没，Ambos 及び Hammer を摘出すると Stapes は可 動性.

卵円及び正円空には組織塊はない，鼓室の粘嗼，特に Promontrium の粘膜は高度に腫脤，但し硬化した部分 は認められない. Hypotympanum の発肖は特に悪い。 Attic 及び鼓室の発育抑制が特に強い，外耳道の皮虔は 皮笥炎のため強度に腫脹。

耳小骨を囲む結合織塊を組織学的に見ると，全体とし ては細胞浸潤の著明な緻密な肉芽組織で，部分的に硝子 化した部分が認められる。この部分が灰白色の顆粒に見 えていた部分である，鼓室粘膜も結合織性の肥厚著明．

本症例では Kalkschale は発見できなかつたが，灰白 色の小顆椟の認められた肉芽塊は年の前段階のむのと見 做される，その他の所見より，Tympanosklerose と見 做さるべき例であつて，含気化の抑制，特に Attic 及 び Tympanum の発育抑制が強い，外耳道皮㢈の強度 の腫脹を伴う外耳炎の存在していたことる特徵であつ て，本例は性来諸種の薬物济対して皮膚炎を起し易い体 質であると言う。

\section{考按}

1) Tympanosklerose の病像について

Tympanosklerose を一つの独立性の西る中耳聅患と する上に必要な所見は，中耳粘膛の Sklerose で就つ

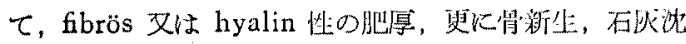
着といらような退行性の变化が認められることである

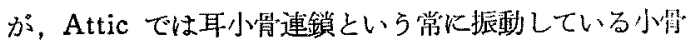
をそのうちに納めているために，硬化した粘膜は更に変 化を進め，遂に，Hyalin 叉仿 Kalkscnale と称する薄 い放状の組織片を耳小骨と骨壁との間に生ずるに至るも のと思われる。斯る变化は当然の結果として耳年骨の Ankylose と高度の Otosklerose 様の難聴をきたすわ けであるが，単に中耳の粘膜に hyalin の変化や，石反 の沈着，特に鼓膜に同様の变化が認められるのみでな く，耳小骨及びその周囲に斯る特異な所見を伴うことに よつて、はじめて Tympanosklerose と䓂断されてよい のではあるまいか。

2）発症の誘因について

中耳粘膜の Sklerose 様の病变は慢性炎症に战西個 体の特異な反応と見做すよりないが，この特異な反心を 
起方条件の一つとして中耳腔, 特に Attic の含気化抑了 制といらことに大きな意義が存在すると思わ机る。

Pneumatisation の悪るい空腔の粘膜が fibrös に反 応することは含気腔の通則である，従つて，Pn．の瑟る い中耳粘膜は fibrös に反応することが考えられる。し かし，てれが更に hyalin 化又は骴澵生を見るに至るた

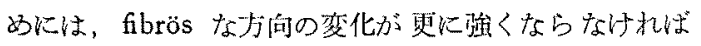

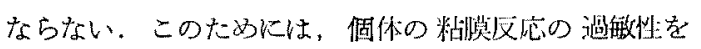
搭えることが妥当のように思う. Zöllner が Allergie を挙げたことにも理四を感ぜられる。著者の2 例では

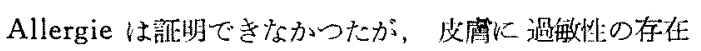
する体質であつたことも本症の成立に甞缐があるのでは 频るまいか。

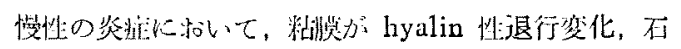

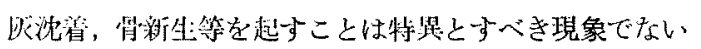
が，耳小能と骨壁との间に遊離した組織片を抢成与るこ とは特異/垷象である。所謂 Hyalin 又は Kalkschale

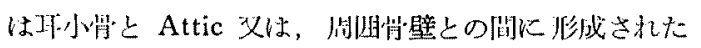
网節の関節顿谓 Meniscus に相当するものと考えたい． 振動している耳小綃は接着した硬い絬合織組織に硬化を 促進し，骨化は骨㥞組織を抢成し，耳小骨との間に関節 形成を起すことが考兵られる。この現象は炎症後の辝膜 に石灰の沈着をきたすことと類似した外力に対する自然 の反応と見做される。

Attic の狭小，粘膜の fibrös な高度な肥厚之，これ による Attic 悾の充塞, 耳小骨の振動とは粘膜の Sklerose を促進し，耳小睛連鎖との間に Meniscus 㥞の組 織を形成与るに至つたものと解釈したい，

3）発症の特期について

Zöllner 及び Harpis 等の意見では推測ではむるが， 本症の成立には長期を要し恐らく小児期より発婝してい たものであるらとしていた，著者の第 2 例の経験から本 症が1年内外の短時間内にて起り得ることが明らかにな つた. 従つて本症が慢性炎症の結果に発症することも確 奜である。

4) Attic の蜂㚌発有異常による耳小骨 Ankylose

Tympanosklerose は中耳粘膜の Sklerose 飞基固し た耳小骨の Ankylose であるが，炎拝によらず，Attic の発㕕障害のために小蜂窂骨壁が耳小骨連鎖と接着すれ ば，絬果に和いては本症と類似の症状を呈する。斯る病 装は Pseudo-otosklerose として総括されることのでき る病変であるが，Tympanosklerose と極めてよく似た
ものであつて, Tympanosklerose の一つの型とも教 られる。

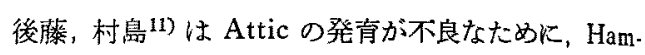
mer の頭部が樑く Attic の小蜂巢内に觔入し, 関節面 を作つている例を 3 例報告した。斯る例は Attic の発 育抑制と言らよりもAttic に小䗋窂の形成の盛ん标 例であつて, Attic 腔へ向つて小蜂案隔壁が笑出して Hammer 㕛は Ambos K接着するに至つたものであ る。但し斯る例に叔いてる骨性の癒合は認められず, 関 節様の分滩面が四骨面の間に認められる. Tympanosk. lerose では Pn. の抑制が存在するから Attic 㷋い

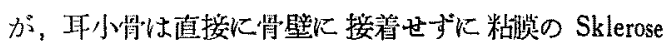

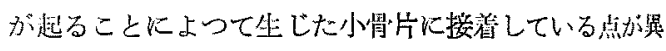

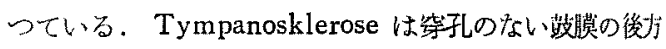
にも見られるものがあるとされて，本掟の成因を考学る ことを困耀にしているが，それは上述のような Attic

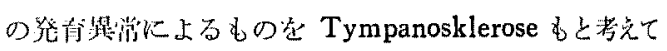
のことではあるまいか.

\section{5) invasive form の説明}

本症には上述の一般の型, 即ち Sklerosing mucositis

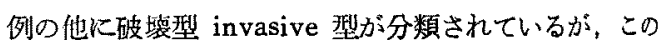
型のわのはいかにして生したものであるか説明は困難で ある. 粘膜の Sklerose が高度になつて骨を吸収するこ とは一般の状態では考光られない，寧万反対の現象が起 るように思かれる。しかし，前項に述べたよらな，既炕 発育の途上に耳小骨が Attic の小蜂笨壁に接着してい る例では，斯る例慢性の強い炎症が起これば，小䗋楅 内粘膜の高度の Sklerose 様变化の起ることに伴つて， その骨壁にも骨の変性が起り，線維骨化し耳小骨々接能 している状態では小骨片の遊崔といらことも起り得るか もしれない. 著者の第 2 例の Amboss の内側の Aditus の骨壁にそのような所見が認められた。

しかし，それる一般の条件下では教られないとど

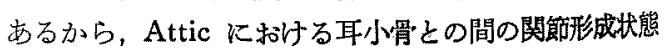
に関連のあるるのと考克ざるを得ない。この型のるのの 成立機序については向後症例について上く检颜する必要 がある。

6) Cholesteatomotitis との鑑別

本症は又 Cholesteatomotitis と謁まられ易い所見を 呈している、第2 例で経験したことであるが，傩室後上 部の上皮が白色を呈する部分は Cholesteatom と思つた が. Cholesteatom と異り，要臭を欠き，剿脱片はなく， Cholesteatom の Matrix とは翼つている。組的的も 
粘战下組織の硝子化によるるので角化扁平上皮への变性 によるるのではない，誤られ易い所見であるが，しか し合併することもあり得る筈である．藤沢 2) る本症と Cholesteatom $の$ 合併例を報告し，Goodhill 9) む肉芽内 $\kappa$ Cholesteatom matrix の存在例を2例記载してある. 本症の発掟の原因が慢性中耳炎と言つても Tympanitis にあることから見て呅室粘膜よりの Cholesteatom であ れば、耳小䯚は吸収される結果となるから，極めて初期 の肉芽内のものでない限りは，別個化上跂室より発愔し たものてなければならない，しかし唼室に穿孔があるの KAttic にも穿孔ができて Cholesteatom の起ること は实際には稀な現象であるから，本病と Cholesteatom との合併とその発应に就ては向後，上く観察すべき点を 残している.

\section{結論}

文献並に3 例の自家経等保例より Tympanosklerose の Pathogenese に就C存察し次の結諭が得られた。

(1) Tympanosklerose は Attic の高度の Pneumatisationshemmung 芝持つことを条件と与ること。

(2) Pn. hemmung は Attic の糊荧に fibrösな反仙 䘮起こし，本症は斯る变化を基礎として発拉すること。

(3) 糊赏の fibrös な反応を增加し更に气の一部化硝 子化々骨化をきたすため溂激の強いことも必要である

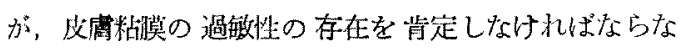
w.

(9) 耳小骨の振動は fibrös な粘膜の骨化と硝子化炍 促進的飞作用すると見られる。

(5) 粘膜の肖化方るいは硝子化によつて Hyalinschale 又は Kalkschale と呼ばれる游踓右能の組織片が形 成される。この組織片と开小岗との間には阔節栚の接触

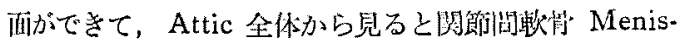
cus 飞相当するものと見做される。
(6) 破壊型は既に Attic の含気化異常によつて骨壁 上りの小䗋笨壁が耳小骨比接着していた例飞炎庭が加 り, 䗋榃内粘膜の硬化に次いで骨の線維化と分劃が起つ たものではあるまいかと推論した。

(7) Tympanosklerose の発症には必ずしも奻封から の長期要要するとは考兄られない

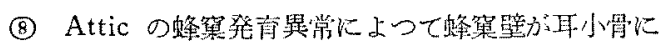
接准してその硬直をきたすもので Tympanosklerose と

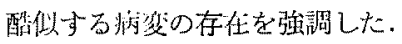

\section{文献}

1) Adam Politzer: Lehrbuch der Ohrenneilkunde fuer praktische Aerzte und Sturierende. 1908. 2) Goodhill: Pseudosclerosis. Laryngoscope 70 : 222, 1960.3$)$ Goodhill: Tympanoplasty in relation to tympanosclerosis and pediatric cholesteatosis. Journal of Oto-rhino-laryng. Society of Japan 62, No. 2 (Supplement): 124, 1961. 4) House and Sheehy: Tympanosclerosis. Arch. Otolaryng. 72: 308, 1960 . 5) Irwin Harris: Tympanosclerosis A revived clinicopathologic entity. Laryngoscope $71: 1488,1961.06)$ Zoellner and Beck: Die Paukensclerose. Zeitschr. Laryng. 34:137, $1955 . \quad 7)$ Zoellner: Tympanosclerosis. Journal Laryng. 70:

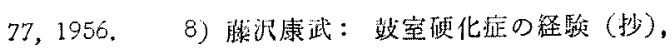
日耳㭷，64:478，1961.99) 藤沢康武：Tympanosclerosis, 耳奥咽, 34: 929, 1962.10) 10田喜郎:

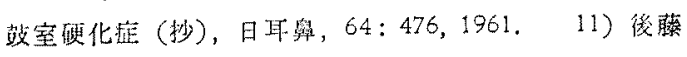

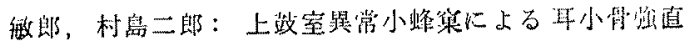
について、日耳鬼, 59: 1209, 1956.

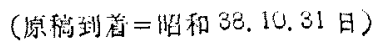

